\title{
Review
}

\section{Agamben and radical politics}

Edited by Daniel McLoughlin

Edinburgh University Press, Edinburgh, 2016, 269pp.,

ISBN: 978-1474402637

Contemporary Political Theory (2017) 16, 585-587. doi:10.1057/s41296-017-0096-0; advance online publication 7 March 2017

I enjoyed reading this book very much. Often writing a review for an edited collection is a difficult task, especially if one has to assess the whole package of contributions in relation to the claims normally made by the editors in terms of what is keeping the volume together. But this is a different case. First, the book follows a workshop held at the University of New South Wales with the contribution of some of the most influential readers of Agamben's oeuvre. Second, Agamben and Radical Politics is opened by an illustrative introduction penned by the editor that helps the reader to clearly identify the twofold objectives of this editorial initiative: on the one hand, to discuss Agamben as a critical thinker of/in relation with the radical Left; on the other, to engage with his most recent work, in order to somehow move beyond the early homo sacer stage that made the Italian philosopher so influential in both the humanities and the social sciences of the past two decades or so. Third, the first chapter is the translation of an important article written by Agamben himself and directly inspired by Walter Benjamin's wellknown essay on capitalism as religion.

In addition to the importance of publishing in English a new contribution from Agamben on the nature of capitalism, I find this opening chapter/article particularly important to set the tone of the volume. Having an Agamben article on capitalism is indeed a powerful way to open the floor to the interventions that follow which are engaging with his diagnosis of contemporary capitalism and his relationship to revolutionary traditions. The book accordingly reflects on Agamben's recent work on poverty and use, work that clearly brings him closer - to speak with the editor 'to the communitarian anarchist tradition' rather than 'to Marx's governmental communism' (p. 7). Agamben and Radical Politics is therefore focused - suggests Daniel Mc Loughlin - on the 'continuing contribution of Agamben's work to legal and political thought by responding to his new works on economy and government'. The volume also 'shows how his work is indebted to the tradition of revolutionary thought and practice ... and considers the benefits and limitations of his contribution to, and attempt to innovate upon, this tradition' (p. 6).

(C) 2017 Macmillan Publishers Ltd. 1470-8914 Contemporary Political Theory Vol. 16, 4, 585-587 www.palgrave.com/journals 
Overall, the book reflects on the relationship between Agamben's work and radical thought by engaging with some of his most recent publications, in particular but not exclusively, with his speculations on the Christian conception of oikonomia as the ultimate form of government marking the secular state, as presented in The Kingdom and the Glory and in other essays that followed. At the same time, Opus Dei and The Highest Poverty are also treated by contributors to this collection as 'gestures' capable of not only initiating a new season of philosophical thought for Agamben, somewhat completing the homo sacer project, but also reacting to the criticism received on his bio/thanapolitical ruminations of the past decades, especially those centred around questions of sovereign power and the state of exception. This new putative Agambenian phase, if I am allowed to describe it as such, is largely scrutinized by several contributions present in this collection, either by a direct engagement with the respective texts, or by confronting Agamben's work with that of other equally relevant authors, like Marx, Foucault, Žižek, Debord, Badiou and Heidegger, to mention a few.

The chapters also discuss, again largely but not exclusively referring to Agamben's most recent writings, the relationship between his work and the capitalist conceptualizations of spectacle, but also questions of anarchism, antagonism, or 'inoperativity' - including his links to the Italian operaismo, a political movement in relation to which, I trust, Agamben's work should also be considered. Finally, some of the chapters analyse even more stringent philosophical themes, for example, Agamben and the katechon, or the Papal revolution, but also the 'Agambenian method', a very important topic if one considers how part of the secondary literature focused on this Italian philosopher has been critical of his use of historical material to support some of his key arguments (for example, his homo sacer genealogical account).

I would like to conclude with a positive note and a critical one: Agamben has undoubtedly been one of the most influential thinkers of the last decade or so. What I find particularly important in this book is the fact that it clearly delivers the sense that the Agambenian project is not over but, on the contrary, that the Italian philosopher, albeit in continuity with his past work, has opened new lines of thought that may help us 'thinking the present'. When reading the essays composing this volume, one is left with a clear feeling that the 'Agamben effect' and its related debates have moved on, well beyond the initial stages of the homo sacer project. As noted above, they have moved on by new engagements around questions of oikonomia and use: on the one hand, by showing clear signs of continuity with his previous work on biopolitics; on the other, by trying to link the present-day forms-of-life to new understandings of government (and sovereignty).

However, if this collection certainly must be praised for representing a sort of state of the art in Agamben studies, and for making a key contribution in thinking through our political situation, at the same time, at least in my opinion, it does not engage enough with the role - real and potential - of Agamben's thought in the 
social sciences, and its potential impact outside of academia. Some of the key concepts related to the homo sacer project have indeed travelled a long way to reach out the shores of critical social theory and feed into the methodologies of research focused on states and spaces of exception, witnessing, camps, borders, homini sacri, etc. They have also helped highlight the importance of the camp and biopolitics in global politics after 9/11, well beyond the limited spaces of academic debates. What remains unclear is how the new phase of Agamben's thought here discussed may potentially impact in the ways, in which the social sciences will treat questions of government, of capitalism, of resistance, of subjectivity, of affirmative biopolitics, to name a few possible venues of exploration that may find inspiration in his most recent work. And how these may indeed impact public discourse more broadly. Perhaps this is suitable task for a new book on Agamben's last decade.

Claudio Minca Wageningen University, 6700 HB Wageningen, The Netherlands claudio.minca@wur.nl 